\title{
Polymorphisms of cell cycle control genes influence the development of sporadic medullary thyroid carcinoma
}

\section{R B Barbieri, N E Bufalo, R Secolin, L V M Assumpção, R M B Maciel' J M Cerutti ${ }^{1}$ and $\mathbf{L} \mathbf{S}$ Ward}

University of Campinas (FCM - Unicamp), 126, Tessalia Vieira de Camargo, Street. Cidade Universitaria Zeferino Vaz, Campinas - São Paulo, 13083-887 Brazil and ${ }^{1}$ Federal University of Sao Paulo (Unifesp), 669, Pedro Toledo Street, São Paulo-SP 04039-032, Brazil
Correspondence should be addressed to L S Ward Email

ward@fcm.unicamp.br

\begin{abstract}
Background: The role of key cell cycle regulation genes such as, CDKN1B, CDKN2A, CDKN2B, and CDKN2C in sporadic medullary thyroid carcinoma (s-MTC) is still largely unknown.

Methods: In order to evaluate the influence of inherited polymorphisms of these genes on the pathogenesis of s-MTC, we used TaqMan SNP genotyping to examine 45 s-MTC patients carefully matched with 98 controls.

Results: A multivariate logistic regression analysis demonstrated that CDKN1B and CDKN2A genes were related to s-MTC susceptibility. The rs $2066827 * \mathrm{GT}+\mathrm{GG}$ CDKN1B genotype was more frequent in s-MTC patients $(62.22 \%)$ than in controls (40.21\%), increasing the susceptibility to s-MTC $(\mathrm{OR}=2.47 ; 95 \% \mathrm{Cl}=1.048-5.833 ; P=0.038)$. By contrast, the rs $11515^{*} \mathrm{CG}+\mathrm{GG}$ of CDKN2A gene was more frequent in the controls $(32.65 \%)$ than in patients $(15.56 \%)$, reducing the risk for s-MTC $(\mathrm{OR}=0.174 ; 95 \%$ $\mathrm{Cl}=0.048-0.627 ; P=0.0075)$. A stepwise regression analysis indicated that two genotypes together could explain $11 \%$ of the total s-MTC risk. In addition, a relationship was found between disease progression and the presence of alterations in the CDKN1A (rs1801270), CDKN2C (rs12885), and CDKN2B (rs1063192) genes. WT rs1801270 CDKN1A patients presented extrathyroidal tumor extension more frequently (92\%) than polymorphic CDKN1A rs 1801270 patients ( $50 \% ; P=0.0376)$. Patients with the WT CDKN2C gene ( $r$ 12885) presented larger tumors $(2.9 \pm 1.8 \mathrm{~cm})$ than polymorphic patients $(1.5 \pm 0.7 \mathrm{~cm} ; P=0.0324)$. On the other hand, patients with the polymorphic CDKN2B gene ( $r$ 1063192) presented distant metastases (36.3\%; $P=0.0261)$.

Conclusion: In summary, we demonstrated that CDKN1B and CDKN2A genes are associated with susceptibility, whereas the inherited genetic profile of $C D K N 1 A, C D K N 2 B$, and CDKN2C is associated with aggressive features of tumors. This study suggests that profiling cell cycle genes may help define the risk and characterize s-MTC aggressiveness.
\end{abstract}

\section{Introduction}

Although responsible for no more than $3-5 \%$ of all thyroid cancers, medullary thyroid carcinoma (MTC) is responsible for more than $14 \%$ of thyroid cancer-related deaths $(1,2)$. The majority of MTC cases $(>75 \%)$ are sporadic MTC (s-MTC), even though up to $40 \%$ of these so-called sporadic cases may be caused by somatic RET mutations (3). Despite the importance of the RET receptor, it is clear that other signal transduction pathways, tyrosine kinase receptors, and tumors suppressor genes are involved in MTC tumorigenesis
(C) 2014 European Society of Endocrinology Printed in Great Britain and progression (4). In fact, the molecular basis of s-MTC is still poorly understood (5). It is plausible that, similar to other malignancies, s-MTC is caused by multiple common genetic variants in different susceptibility genes commonly called 'low-penetrance genes' (6).

Dysregulation of the cell cycle is a hallmark of many cancers $(7,8,9)$. Control and timing of the cell cycle involve checkpoints and regulatory pathways that ensure the fidelity of DNA replication and chromosome 
segregation (10). Alterations of genes involved in the G1 phase of the cell cycle, including the cyclins, cyclindependent kinases (CDKs), and CDK inhibitors (CDKIs), are common events in neoplastic development of a series of different types of tumors (11). Their role in s-MTC is still largely unknown.

Thyroid tumors show low expression of the CDKI P27 (Kip1), and recent evidence has demonstrated that P27 is downregulated by the active RET mutant (12). These data suggest that a decreased P27 (CDKN1B) activity is an important event during thyroid tumorigenesis. However, $p 27^{-/-}$mice develop MEN-like tumors only in combination with the loss of another CDKI, $p 18$ (Ink4c). Hence, it is possible that $p 18$ (Cdkn2c) and $p 27$ are functional collaborators in the suppression of tumorigenesis, and that the loss of both may also be important to MTC development (12).

There have been some reports associating polymorphisms of cell cycle genes with s-MTC $(13,14,15,16)$. The CDKN1B V109G polymorphism was reported to influence the clinical course of patients presenting sporadic MTC (15). In addition, cell cycle and apoptosis regulators have long been recognized as critical in the initiation of malignant cell proliferation and this study has recently demonstrated the influence of the presence of a C homozygous allele for the TP53 gene on the susceptibility to s-MTC (17).

This study aimed to evaluate the role of genetic variations in key cell cycle regulation genes CDKN1A, $C D K N 1 B, C D K N 2 A, C D K N 2 B$, and $C D K N 2 C$ in sporadic medullary thyroid cancer pathogenesis.

\section{Patients and methods}

This study was approved by the Ethics and Research Committees of the Federal University of São Paulo (Unifesp) and the State University of Campinas (Unicamp).

\section{Patients}

A total of 45 patients diagnosed with s-MTC based on cytology and elevated serum calcitonin levels, and who have signed an informed consent form, were enrolled in this study. As described previously, none of the s-MTC patients had any other types of malignant tumor or any history of thyroid tumor in first-degree relatives (14). All patients were sequenced for the complete RET gene and no mutation was identified. Ninety-eight healthy individuals from the same region and matched for sex and age with the enrolled patients served as controls. Individuals with a history of past thyroid disease and antecedents of malignancy were excluded. An in-person questionnaire, described previously, was used to collect demographic and health condition information (17). All data, including nodule size, tumor histological features, and laboratory test results, were confirmed using the hospital records of the patient. All patients were managed using the same standard protocol according to the recommendations of current guidelines $(18,19)$.

\section{Genotyping}

DNA was extracted from peripheral blood leukocytes obtained from both patients and controls using a standard phenol-chloroform protocol. Nine polymorphisms were genotyped: CDKN1A (rs1801270 and rs1059234), CDKN1B (rs2066827 and rs34330), CDKN2A (rs11515), CDKN2B (rs2069426, rs3731239, and rs1063192), and CDKN2C (rs12885) using the TaqMan system (Applied Biosystems), as described previously (17). These SNPs were chosen because they have previously been associated with thyroid carcinoma or other tumor risks as described in Table 1 $(13,15,16,20,21,22)$.

\section{Statistical analysis}

The $t$-test and the Fisher exact test were employed in order to evaluate differences in age and sex using the SAS statistical software (Statistical Analysis System, version 9.1.3, 2002-2003). For comparison of continuous or orderable variables between two groups, we applied the Mann-Whitney $U$ test. The Hardy-Weinberg equilibrium (HWE) and linkage disequilibrium between SNPs were performed using the HAPLOVIEW software (23). Logistic and stepwise regressions were used to analyze the association between polymorphisms and genes using the

Table 1 Sequence-specific primers used for genotyping $C D K N 1 B, C D K N 1 A, C D K N 2 C, C D K N 2 A$, and CDKN2B genes and the corresponding reference of their description in the risk of other tumors.

\begin{tabular}{|c|c|c|}
\hline Genes & SNP & Registration applied \\
\hline \multirow[t]{2}{*}{$p 27-C D K N 1 B$} & rs2066827 & C_11916245_10 \\
\hline & rs34330 & C_2402292_10 \\
\hline$p 21-C D K N 1 A$ & rs1801270 & C_14977_20 \\
\hline$p 18-C D K N 2 C$ & rs12885 & C_1452499_10 \\
\hline \multirow[t]{2}{*}{$p 16-C D K N 2 A$} & rs11515 & C_12096259_10 \\
\hline & rs3088440 & C_16008027_10 \\
\hline \multirow[t]{3}{*}{$p 15-C D K N 2 B$} & rs2069426 & C_15858974_10 \\
\hline & rs3731239 & C_27974751_10 \\
\hline & rs1063192 & C_2618046_10 \\
\hline
\end{tabular}


R software (24). All $P$ values were adjusted for multiple comparisons by the Bonferroni correction. Post-hoc statistical power of the sample was evaluated using the GPower software (25), with a statistically significant level of $\leq 0.05$ for all tests.

\section{Results}

Sporadic MTC patients (15 males and 30 females; $42.20 \pm$ 12.30 years old) and controls (30 males and 68 females; $40.30 \pm 11.20$ years old) were similar concerning age $(P=0.356)$ and sex $(P=0.745)$. The rs1059234 polymorphism of CDKN1A was not in the HWE, possibly because of the relatively small size of the studied groups and the high genetic heterogeneity of the Brazilian population. Thereby, this polymorphism was excluded from further statistical analyses.

\section{Influence of cell cycle control gene polymorphisms on the susceptibility to s-MTC}

A univariate logistic regression, given in Table 2, showed associations between s-MTC and the following genotypes:
rs2066827*GT $(P=0.0014 ; \mathrm{OR}=3.48 ; 95 \% \mathrm{CI}=1.67-7.29)$ and rs2066827*TT $(P=0.0299 ; \mathrm{OR}=0.41 ; 95 \% \mathrm{CI}=0.20$ 0.86), in the $C D K N 1 B$ gene; and $r s 11515^{*} \mathrm{C} / \mathrm{C}(P=0.0324$; $\mathrm{OR}=2.51 ; \quad 95 \% \quad \mathrm{CI}=1.02-6.16) \quad$ and $\mathrm{rs} 11515^{*} \mathrm{CG}$ $(P=0.0432 ; \quad \mathrm{OR}=0.42 ; 95 \% \mathrm{CI}=0.17-1.03)$, in the CDKN2A gene.

A multivariate logistic regression analysis confirmed the importance of the inheritance of $C D K N 1 B$ and $C D K N 2 A$ gene variants $(\mathrm{OR}=2.472$ and $\mathrm{OR}=0.174$ respectively), as detailed in Table 3 .

The rs2066827*GT + GG CDKN1B genotype was overrepresented in s-MTC patients $(62.22 \%)$ when compared with controls $(40.21 \% ; P=0.038)$, increasing substantially the susceptibility to s-MTC $(\mathrm{OR}=2.47 ; 95 \% \mathrm{CI}=1.048$ 5.833; $P=0.038)$. By contrast, the polymorphic rs $11515^{*} \mathrm{CG}+\mathrm{GG}$ of the $C D K N 2 A$ gene was more expressed in the control population (32.65\%) than in s-MTC patients (15.56\%; $P=0.0075)$, reducing the risk of developing $\mathrm{s}-\mathrm{MTC}(\mathrm{OR}=0.174 ; 95 \% \mathrm{CI}=0.048-0.627 ; P=0.0075)$.

A stepwise regression analysis indicated that, in our sample, CDKN1B rs2066827*GT genotype contributed to $8 \%$ for the total risk of developing an s-MTC, whereas CDKN2A rs $11515^{*} \mathrm{CC}$ contributed to $3 \%$. These two

Table 2 Genotyping characteristics of patients with sporadic medullary thyroid cancer (s-MTC) compared with the group of controls.

\begin{tabular}{|c|c|c|c|}
\hline Genes & SNP & Genotype & s-MTC (\%) \\
\hline \multirow[t]{6}{*}{$C D K N 1 B$} & rs2066827 & GG & 37.78 \\
\hline & & GT & 57.78 \\
\hline & & TT & 4.44 \\
\hline & rs34330 & $\mathrm{CC}$ & 60.00 \\
\hline & & $\mathrm{CT}$ & 37.78 \\
\hline & & TT & 2.22 \\
\hline \multirow[t]{3}{*}{ CDKN1A } & rs1801270 & AA & 82.93 \\
\hline & & $A C$ & 17.07 \\
\hline & & $\mathrm{CC}$ & 0.00 \\
\hline \multirow[t]{3}{*}{$C D K N 2 C$} & rs12885 & GG & 70.73 \\
\hline & & $\mathrm{GT}$ & 26.83 \\
\hline & & TT & 2.44 \\
\hline \multirow[t]{3}{*}{$C D K N 2 A$} & rs11515 & CC & 84.44 \\
\hline & & CG & 15.56 \\
\hline & & GG & 0.00 \\
\hline \multirow[t]{9}{*}{$C D K N 2 B$} & rs2069426 & $\mathrm{AA}$ & 86.67 \\
\hline & & CA & 4.44 \\
\hline & & $\mathrm{CC}$ & 8.89 \\
\hline & rs3731239 & $\mathrm{AA}$ & 55.00 \\
\hline & & AG & 45.00 \\
\hline & & GG & 0.00 \\
\hline & rs1063192 & $\mathrm{CC}$ & 55.56 \\
\hline & & $\mathrm{TC}$ & 26.67 \\
\hline & & $\mathrm{TT}$ & 17.78 \\
\hline
\end{tabular}

\begin{tabular}{c}
\hline \\
Controls $(\%)$ \\
\hline 59.79 \\
27.84 \\
12.37 \\
51.04 \\
39.58 \\
9.38 \\
67.01 \\
27.84 \\
5.15 \\
77.32 \\
22.68 \\
0.00 \\
67.35 \\
31.63 \\
1.02 \\
75.53 \\
14.89 \\
9.57 \\
57.89 \\
30.53 \\
11.58 \\
53.13 \\
37.50 \\
9.38 \\
\hline
\end{tabular}

\begin{tabular}{c}
\hline \\
\hline Pvalue $^{a}$ \\
\hline 0.3155 \\
0.0014 \\
0.0299 \\
0.5940 \\
1.0000 \\
0.2070 \\
1.0000 \\
0.4381 \\
0.5577 \\
0.3949 \\
0.5631 \\
0.2058 \\
0.0324 \\
0.0432 \\
0.8335 \\
1.0000 \\
0.1915 \\
0.1858 \\
1.0000 \\
0.8044 \\
1.0000 \\
0.4257 \\
0.6055 \\
1.0000 \\
\end{tabular}

\begin{tabular}{l}
\hline \\
\hline OR \\
\hline 0.39 \\
3.48 \\
0.41 \\
1.46 \\
0.95 \\
0.28 \\
1.17 \\
0.59 \\
1.53 \\
0.71 \\
1.27 \\
6.64 \\
2.51 \\
0.42 \\
0.71 \\
0.75 \\
0.31 \\
2.34 \\
0.72 \\
1.51 \\
0.94 \\
2.14 \\
0.61 \\
1.10 \\
\end{tabular}

\begin{tabular}{|c|c|}
\hline \multicolumn{2}{|c|}{$95 \% \mathrm{Cl}$} \\
\hline High & Low \\
\hline 0.09 & 1.68 \\
\hline 1.67 & 7.29 \\
\hline 0.20 & 0.86 \\
\hline 0.71 & 2.98 \\
\hline 0.46 & 1.96 \\
\hline 0.05 & 1.74 \\
\hline 0.28 & 4.84 \\
\hline 0.25 & 1.41 \\
\hline 0.69 & 3.39 \\
\hline 0.32 & 1.57 \\
\hline 0.56 & 2.86 \\
\hline 0.07 & 622.36 \\
\hline 1.02 & 6.16 \\
\hline 0.17 & 1.03 \\
\hline 0.01 & 66.93 \\
\hline 0.23 & 2.42 \\
\hline 0.07 & 1.28 \\
\hline 0.90 & 6.05 \\
\hline 0.36 & 1.46 \\
\hline 0.73 & 3.15 \\
\hline 0.31 & 2.82 \\
\hline 0.77 & 5.96 \\
\hline 0.28 & 1.33 \\
\hline 0.54 & 2.24 \\
\hline
\end{tabular}

${ }^{\mathrm{a}}$ Corrected by the Bonferroni adjustment. 
Table 3 Comparison between genotyping profiles CDKN1B and CDKN2A of patients with sporadic medullary thyroid carcinoma (s-MTC) and control population, using multivariate logistic regression analysis.

\begin{tabular}{|c|c|c|c|c|c|c|c|c|}
\hline \multirow[b]{2}{*}{ Genes } & \multirow[b]{2}{*}{ SNP } & \multirow[b]{2}{*}{ Genotype } & \multirow[b]{2}{*}{ S-MTC (\%) } & \multirow[b]{2}{*}{ Controls $(\%)$} & \multirow[b]{2}{*}{ P value $^{a}$} & \multirow[b]{2}{*}{ OR } & \multicolumn{2}{|c|}{$95 \% \mathrm{Cl}$} \\
\hline & & & & & & & High & Low \\
\hline$C D K N 1 B$ & rs2066827 & $\begin{array}{l}\mathrm{GG} \\
\mathrm{GT}+\mathrm{TT}\end{array}$ & $\begin{array}{l}37.78 \\
62.22\end{array}$ & $\begin{array}{l}59.79 \\
40.21\end{array}$ & 0.0388 & 2.472 & 1.048 & 5.833 \\
\hline$C D K N 2 A$ & rs11515 & $\begin{array}{l}\mathrm{CC} \\
\mathrm{CG}+\mathrm{GG}\end{array}$ & $\begin{array}{l}84.44 \\
15.56\end{array}$ & $\begin{array}{l}67.35 \\
32.65\end{array}$ & 0.0075 & 0.174 & 0.048 & 0.627 \\
\hline
\end{tabular}

${ }^{a}$ corrected by Bonferroni adjustment.

genotypes together could explain $11 \%$ of the total s-MTC risk (Fig. 1).

\section{Genotype relationship with features of aggressiveness in patients with s-MTC}

For these analyses, patients were divided into two groups: WT (homozygous normal alleles) and polymorphic (a combination of homozygous polymorphic + heterozygous alleles), for each gene. Clinical and pathological characteristics, including age, sex, tumor stage (T, N, and $\mathrm{M})$, and size, extra thyroidal extension, serum calcitonin levels, and recurrence in patients were analyzed and compared with their genetic profile.

The Mann-Whitney $U$ test demonstrated that patients with WT gene presented extrathyroidal tumor extension more frequently $(92 \%)$ than patients with polymorphic gene in rs1801270 CDKN1A gene $(50 \% ; P=0.0376)$.

Patients with WT CDKN2C gene (rs12885) presented larger tumors $(2.9 \pm 1.8 \mathrm{~cm})$ than patients with polymorphic gene $(1.5 \pm 0.7 \mathrm{~cm} ; P=0.0324)$. By contrast, only patients with polymorphic CDKN2B gene (rs1063192) presented distant metastases (36.3\%; $P=0.0261)$.

We were unable to find any other associations between the profile of the studied genes and the clinical or pathological characteristics of patients.

\section{Discussion}

This case-control study is, to the best of our knowledge, the first to investigate the association of $C D K N 1 B$, $C D K N 1 A, C D K N 2 C, C D K N 2 A$, and CDKN2B polymorphisms and the susceptibility to s-MTC. Besides the demonstration that $C D K N 1 B$ and $C D K N 2 A$ genes were related to s-MTC susceptibility, this study also found evidences that $C D K N 1 A, C D K N 2 B$, and $C D K N 2 C$ gene variants are associated with tumor features of aggressiveness.
Recent studies have indicated that SNPs of genes in cell cycle control play an important role in carcinogenesis and may lead to altered susceptibility to different cancers $(26,27,28)$. An association of CDKN1B (rs2066827) and CDKN2A (rs11515) gene variants was found with the presence of $s$-MTC. It was demonstrated that the rs2066827*GT + GG CDKN1B genotype was overrepresented in s-MTC patients when compared with controls, increasing the susceptibility to this tumor.

The codon 109 in the CDKN1B gene SNP results in a valine to glycine $(\mathrm{T}>\mathrm{G})$ substitution (V109G - rs2066827) (29). The $G$ allele of the CDKN1B gene (rs2066827) has been associated with an increased risk for thyroid (13), squamous cell (28), prostate, and breast cancers $(27,30)$. However, whether this polymorphism is associated with a better or worse prognosis remains uncertain $(13,21$, 28, 31). Pasqualini et al. also found differences in the frequency of the WT (TT $-53.6 \%$ ) and polymorphic alleles

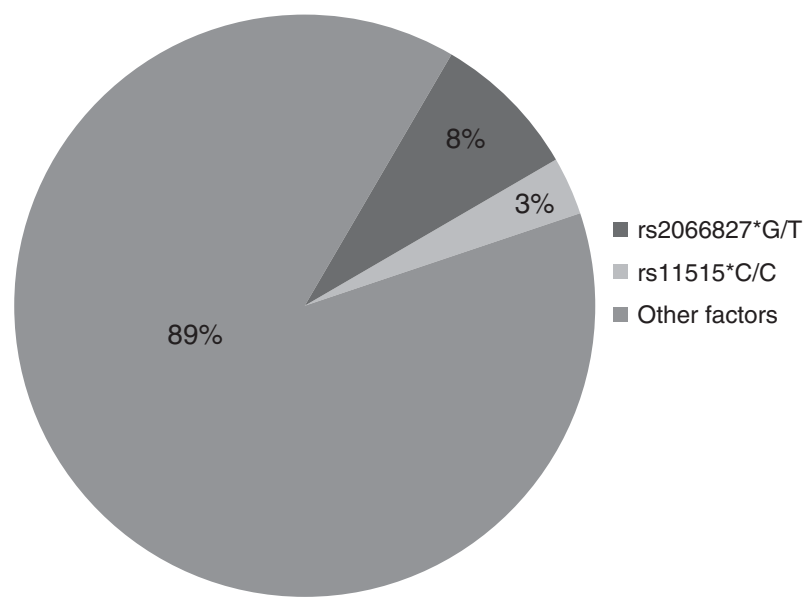

Figure 1

Graphical representation of the relative contribution of the CDKN1B and CDKN2A genes to sporadic medullary thyroid carcinoma risk according to a stepwise regression analysis. 
(TG + GG - 46.4\%) between patients and controls $(P=0.048)$, suggesting a risk of the disease in individuals bearing the CDKN1B rs2066827 polymorphic allele (13). The V109Gl polymorphism falls within a region (amino acids 97-151) that physically interacts with the activation of the domain-binding protein, which triggers the proteolytic degradation of P27 (32). In fact, a reduced P27 expression has been associated with a poor clinical prognosis in head and neck tumors (33). In addition, it has been demonstrated that amino acid changes around position 108, such as the ones induced by V109G polymorphism, can reduce P27kip1 cytosolic translocation, increasing its nuclear stability $(31,34)$. However, no evidence has been provided to support the association of CDKN1B polymorphisms with tumor progression or outcome in MTC (15).

In the study population, polymorphic rs $11515^{*} \mathrm{CG}+$ GG of $C D K N 2 A$ gene was expressed more in the control population than in s-MTC patients, hence presenting a protective effect to s-MTC development. CDKN2A gene polymorphisms have largely been investigated in different types of cancers $(20,22,35)$. The SNP (rs11515 - C98A) CDKN2A gene determines a non-synonymous serine-to-arginine substitution located in the $3^{\prime}$-UTR of exon 3 (36). In fact, similarly, we observed for s-MTC, CDKN2A gene rs11515 polymorphism was also considered a protective factor against cervical cancer (35). CDKN2A gene (rs11515) polymorphism may affect the DNAbinding zinc finger motif, thus modifying p21 expression and function (37). Additionally, the overexpression of p21 has been demonstrated to prevent mammalian cell proliferation and inhibit all cyclin-CDK complexes, suggesting that p21 is a universal inhibitor of cyclinCDK complexes (38).

We also found a relationship between tumor aggressiveness and the presence of variants of the CDKN1A (rs1801270), CDKN2C (rs12885), and CDKN2B (rs1063192) genes.

Patients presenting polymorphic CDKN1A (rs1801270) less frequently have extrathyroidal tumor extension, suggesting that the inheritance of this CDKN1A polymorphism may be associated with a better outcome. A study of cervical cancer in a Chinese population also showed a significant association between the polymorphic allele of the CDKN1A (rs1801270) gene and a decreased risk of disease (39). CDKN1A (rs1801270) polymorphisms were demonstrated to increase the risk of second primary malignancy in patients with index squamous cell carcinoma of head and neck (31). The SNP (rs1801270) within the CDKN1A codon 31 results in a substitution of arginine for serine in a conserved region of the protein and may affect the DNA-binding affinity and thus the physiological function of p21 (40). The p21 protein plays a role in cell cycle regulation. It binds to cyclin-CDK complexes to arrest cell cycle progression at the G1 phase. The transcription of p21 is partially regulated by p53, which binds to the $\mathrm{p} 21$ promoter and induces expression of p21. Therefore, alterations in the functional domains as well as in the promoter region of $\mathrm{p} 21$ could be affected by SNPs and affect p21 functionality (41). CDKN1A is often misregulated in human cancers, but depending on the cellular context and other circumstances, it can act both as a tumor suppressor and as an oncogene (42).

The molecular mechanism underlying a possible protective effect of the CDKN1A (rs1801270) and CDKN2C (rs12885) polymorphic alleles in cancer is unclear. The CDKN2C gene, involved in cell cycle regulation, is located at $1 \mathrm{p} 32$. A frequent finding in MTC tumors is the loss of heterozygosity at chromosome $1 \mathrm{p}$, indicating a potential tumor suppressor gene in this locus (4). Homozygous deletion of the CDKN2C gene was also observed in the human MTC cell line (TT) bearing a RET mutation (16). These data indicate that the CDKN2C gene may act as a tumor suppressor and may facilitate MTC development (4).

Regarding CDKN2B gene polymorphism (rs1063192), we found distant metastases only in polymorphic patients, suggesting an association of this polymorphism with tumor aggressiveness. The polymorphism rs1063192 is located within a gene encoding $C D K N 2 B$, which is also known as $p 15$ (CDKN2B), a well-known tumor suppressor gene involved in the retinoblastoma $(\mathrm{Rb})$ pathway (43). This region on chromosome 9p21 was implicated as a hotspot locus showing the association with various diseases, including myocardial infarction $(44,45)$, coronary artery disease $(46,47)$, type 2 diabetes $(48,49)$, glioma (50), and endometriosis (51); however, there is no report of a possible effect in thyroid cancer.

In conclusion, we found evidence that variations in some cell cycle genes are associated with both susceptibility and progression of s-MTC. As usually observed in studies concerning the effects of polymorphisms, no one demonstrated a highly significant association (52). Although functional evaluation and larger studies are needed to confirm the observed associations, our findings contribute to the identification of the various factors involved in the pathogenesis of s-MTC. It is suggested that profiling cell cycle genes may help define the risk for s-MTC and characterize tumor aggressiveness. 
Declaration of interest

The authors declare that there is no conflict of interest that could be perceived as prejudicing the impartiality of the research reported.

\section{Funding}

This study was supported by the State of São Paulo Research Foundation (FAPESP) under the grant number 07067-5. L S Ward, R M B Maciel, and J M Cerutti are researchers of the National Council for Scientific and Technological Development (CNPq).

\section{Acknowledgements}

The authors thank the team of statisticians of the Faculty of Medical Sciences and Espaço da Escrita - Coordenadoria Geral da Universidade UNICAMP - for the language services provided and for all their valuable suggestions and insights.

\section{References}

1 Massoll N \& Mazzaferri EL. Diagnosis and management of medullary thyroid carcinoma. Clinics in Laboratory Medicine 200424 49-83. (doi:10.1016/j.cll.2004.01.006)

2 Sippel RS, Kunnimalaiyaan M \& Chen H. Current management of medullary thyroid cancer. Oncologist 200813 539-547. (doi:10.1634/ theoncologist.2007-0239)

3 Asai N, Jijiwa M, Enomoto A, Kawai K, Maeda K, Ichiahara M, Murakumo Y \& Takahashi M. RET receptor signaling: dysfunction in thyroid cancer and Hirschsprung's disease. Pathology International 2006 56 164-172. (doi:10.1111/j.1440-1827.2006.01942.x)

4 Santarpia L, Ye L \& Gagel RF. Beyond RET: potential therapeutic approaches for advanced and metastatic medullary thyroid carcinoma. Journal of Internal Medicine 2009266 99-113. (doi:10.1111/j.1365-2796. 2009.02112.x)

$5 \mathrm{Hu}$ MI \& Cote GJ. Medullary thyroid carcinoma: who's on first? Thyroid 201222 451-453. (doi:10.1089/thy.2012.2205.ed)

6 Risch NJ. Searching for genetic determinants in the new millennium. Nature 2000405 847-856. (doi:10.1038/35015718)

7 Butt AJ, Caldon CE, McNeil CM, Swarbrick A, Musgrove EA \& Sutherland RL. Cell cycle machinery: links with genesis and treatment of breast cancer. Advances in Experimental Medicine and Biology $2008 \mathbf{6 3 0}$ 189-205. (doi:10.1007/978-0-387-78818-0_12)

8 Nam EJ \& Kim YT. Alteration of cell-cycle regulation in epithelial ovarian cancer. International Journal of Gynecological Cancer $2008 \mathbf{1 8}$ 1169-1182. (doi:10.1111/j.1525-1438.2008.01191.x)

9 Pharoah PD, Tyrer J, Dunning AM, Easton DF \& Ponder BA. Association between common variation in 120 candidate genes and breast cancer risk. PLoS Genetics 20073 e42. (doi:10.1371/journal.pgen.0030042)

10 Elledge SJ. Cell cycle checkpoints: preventing an identity crisis. Science 1996274 1664-1672. (doi:10.1126/science.274.5293.1664)

11 Barbieri F, Cagnoli M, Ragni N, Foglia G, Bruzzo C, Pedulla F \& Alama A. Increased cyclin D1 expression is associated with features of malignancy and disease recurrence in ovarian tumors. Clinical Cancer Research 19995 1837-1842.

12 Joshi PP, Kulkarni MV, Yu BK, Smith KR, Norton DL, van Veelen W, Hoppener JW \& Franklin DS. Simultaneous downregulation of CDK inhibitors p18(Ink4c) and P27(Kip1) is required for MEN2A-RETmediated mitogenesis. Oncogene 200726 554-570. (doi:10.1038/sj.onc. 1209811)

13 Landa I, Montero-Conde C, Malanga D, De Gisi S, Pita G, LeandroGarcia LJ, Inglada-Perez L, Leton R, De Marco C, Rodriguez-Antona C et al. Allelic variant at $-79(\mathrm{C}>\mathrm{T})$ in CDKN1B (P27Kip1) confers an increased risk of thyroid cancer and alters mRNA levels. EndocrineRelated Cancer 201017 317-328. (doi:10.1677/ERC-09-0016)

14 Marinoni I \& Pellegata NS. P27kip1: a new multiple endocrine neoplasia gene? Neuroendocrinology 201193 19-28. (doi:10.1159/ 000320366)

15 Pasquali D, Circelli L, Faggiano A, Pancione M, Renzullo A, Elisei R, Romei C, Accardo G, Coppola VR, De Palma M et al. CDKN1B V109G polymorphism a new prognostic factor in sporadic medullary thyroid carcinoma. European Journal of Endocrinology 2011164 397-404. (doi:10.1530/EJE-10-0929)

16 van Veelen W, Klompmaker R, Gloerich M, van Gasteren CJ, Kalkhoven E, Berger R, Lips CJ, Medema RH, Hoppener JW \& Acton DS. P18 is a tumor suppressor gene involved in human medullary thyroid carcinoma and pheochromocytoma development. International Journal of Cancer 2009124 339-345. (doi:10.1002/ijc.23977)

17 Barbieri RB, Bufalo NE, Secolin R, Silva AC, Assumpcao LV, Maciel RM, Cerutti JM \& Ward LS. Evidence that polymorphisms in detoxification genes modulate the susceptibility for sporadic medullary thyroid carcinoma. European Journal of Endocrinology 2012166 241-245. (doi:10.1530/EJE-11-0843)

18 Kloos RT, Eng C, Evans DB, Francis GL, Gagel RF, Gharib H, Moley JF, Pacini F, Ringel MD, Schlumberger M et al. Medullary thyroid cancer: management guidelines of the American Thyroid Association. Thyroid 200919 565-612. (doi:10.1089/thy.2008.0403)

19 Tincani AJ, Teixeira GV, Tavares MR, Hojaij FC, Araújo PPC, Maia AL, Ward LS, Kimura ET, Del Negro A, Friguglieti CUM et al. Cancer Medular de Tireoide - Tratamento. Diretrizes Clínicas na Saúde Suplementar 2011: http://www.projetodiretrizes.org.br/ans/diretrizes/ cancer_medular_de_tireoide-tratamento.pdf.

20 Costa-Guda J, Soong CP, Parekh VI, Agarwal SK \& Arnold A. Germline and somatic mutations in cyclin-dependent kinase inhibitor genes CDKN1A, CDKN2B, and CDKN2C in sporadic parathyroid adenomas. Hormones \& Cancer 20134 301-307. (doi:10.1007/ s12672-013-0147-9)

21 Liu F, Wei YG, Luo LM, Wang WT, Yan LN, Wen TF, Xu MQ, Yang JY \& Li B. Genetic variants of $\mathrm{p} 21$ and $\mathrm{p} 27$ and hepatocellular cancer risk in a Chinese Han population: a case-control study. International Journal of Cancer 2013132 2056-2064. (doi:10.1002/ijc.27885)

22 Tuna G, Kucukhuseyin O, Arikan S, Kaytan Saglam E, Guler E, Cacina C, Oztop O, Turan S, Korkmaz G \& Yaylim I. Do CDKN2 p16 540 C > G, CDKN2 p16 $580 \mathrm{C}>\mathrm{T}$, and MDM2 SNP309 T > G gene variants act on colorectal cancer development or progression? DNA and Cell Biology 201332 400-408. (doi:10.1089/dna.2012.1933)

23 Barrett JC, Fry B, Maller J \& Daly MJ. Haploview: analysis and visualization of LD and haplotype maps. Bioinformatics 200521 263-265. (doi:10.1093/bioinformatics/bth457)

24 Hothorn T \& Leisch F. Case studies in reproducibility. Briefings in Bioinformatics 201112 288-300. (doi:10.1093/bib/bbq084)

25 Faul F, Erdfelder E, Lang AG \& Buchner A. G*Power 3: a flexible statistical power analysis program for the social, behavioral, and biomedical sciences. Behavior Research Methods 200739 175-191. (doi:10.3758/BF03193146)

26 Gayther SA, Song H, Ramus SJ, Kjaer SK, Whittemore AS, Quaye L, Tyrer J, Shadforth D, Hogdall E, Hogdall C et al. Tagging single nucleotide polymorphisms in cell cycle control genes and susceptibility to invasive epithelial ovarian cancer. Cancer Research 200767 3027-3035. (doi:10.1158/0008-5472.CAN-06-3261)

27 Kibel AS, Suarez BK, Belani J, Oh J, Webster R, Brophy-Ebbers M, Guo C, Catalona WJ, Picus J \& Goodfellow PJ. CDKN1A and CDKN1B polymorphisms and risk of advanced prostate carcinoma. Cancer Research 200363 2033-2036.

28 Li G, Sturgis EM, Wang LE, Chamberlain RM, Spitz MR, El-Naggar AK, Hong WK \& Wei Q. Association between the V109G polymorphism of the p27 gene and the risk and progression of oral squamous cell 
carcinoma. Clinical Cancer Research 200410 3996-4002. (doi:10.1158/ 1078-0432.CCR-04-0089)

29 Cave H, Martin E, Devaux I \& Grandchamp B. Identification of a polymorphism in the coding region of the p27Kip1 gene. Annales de Genetique 199538108.

30 Figueiredo JC, Knight JA, Cho S, Savas S, Onay UV, Briollais L, Goodwin PJ, McLaughlin JR, Andrulis IL \& Ozcelik H. Polymorphisms cMyc-N11S and p27-V109G and breast cancer risk and prognosis. BMC Cancer 20077 99. (doi:10.1186/1471-2407-7-99)

31 Wang Z, Sturgis EM, Zhang F, Lei D, Liu Z, Xu L, Song X, Wei Q \& Li G. Genetic variants of $\mathrm{p} 27$ and $\mathrm{p} 21$ as predictors for risk of second primary malignancy in patients with index squamous cell carcinoma of head and neck. Molecular Cancer 201211 17. (doi:10.1186/1476-4598-11-17)

32 Tomoda K, Kubota Y \& Kato J. Degradation of the cyclin-dependentkinase inhibitor p27Kip1 is instigated by Jab1. Nature 1999398 160-165. (doi:10.1038/18230)

33 Kudo Y, Takata T, Ogawa I, Kaneda T, Sato S, Takekoshi T, Zhao M, Miyauchi M \& Nikai H. p27Kip1 accumulation by inhibition of proteasome function induces apoptosis in oral squamous cell carcinoma cells. Clinical Cancer Research 20006 916-923.

34 Driver KE, Song H, Lesueur F, Ahmed S, Barbosa-Morais NL, Tyrer JP, Ponder BA, Easton DF, Pharoah PD \& Dunning AM. Association of single-nucleotide polymorphisms in the cell cycle genes with breast cancer in the British population. Carcinogenesis 200829 333-341. (doi:10.1093/carcin/bgm284)

35 Thakur N, Hussain S, Nasare V, Das BC, Basir SF \& Bharadwaj M. Association analysis of p16 (CDKN2A) and RB1 polymorphisms with susceptibility to cervical cancer in Indian population. Molecular Biology Reports 201239 407-414. (doi:10.1007/s11033-011-0752-z)

36 Sherr CJ \& Roberts JM. CDK inhibitors: positive and negative regulators of G1-phase progression. Genes and Development 199913 1501-1512. (doi:10.1101/gad.13.12.1501)

37 Chedid M, Michieli P, Lengel C, Huppi K \& Givol D. A single nucleotide substitution at codon 31 (Ser/Arg) defines a polymorphism in a highly conserved region of the p53-inducible gene WAF1/CIP1. Oncogene 1994 9 3021-3024

38 Polyak K, Kato JY, Solomon MJ, Sherr CJ, Massague J, Roberts JM \& Koff A. p27Kip1, a cyclin-Cdk inhibitor, links transforming growth factor- $\beta$ and contact inhibition to cell cycle arrest. Genes and Development 19948 9-22. (doi:10.1101/gad.8.1.9)

39 Wang N, Wang S, Zhang Q, Lu Y, Wei H, Li W, Zhang S, Yin D \& Ou Y. Association of p21 SNPs and risk of cervical cancer among Chinese women. BMC Cancer 201212 589. (doi:10.1186/1471-2407-12-589)

40 Facher EA, Becich MJ, Deka A \& Law JC. Association between human cancer and two polymorphisms occurring together in the p21Waf1/Cip1 cyclin-dependent kinase inhibitor gene. Cancer 199779 2424-2429. (doi:10.1002/(SICI)1097-0142(19970615)79:12< 2424::AID-CNCR19>3.0.CO;2-T)
41 Roh JW, Kim BK, Lee CH, Kim J, Chung HH, Kim JW, Park NH, Song YS, Park SY \& Kang SB. P53 codon 72 and p21 codon 31 polymorphisms and susceptibility to cervical adenocarcinoma in Korean women. Oncology Research 201018 453-459. (doi:10.3727/ 096504010X12671222663719)

42 Ma H, Chen J, Pan S, Dai J, Jin G, Hu Z, Shen H \& Shu Y. Potentially functional polymorphisms in cell cycle genes and the survival of non-small cell lung cancer in a Chinese population. Lung Cancer 2011 73 32-37. (doi:10.1016/j.lungcan.2010.11.001)

43 Devlin B \& Roeder K. Genomic control for association studies. Biometrics 199955 997-1004. (doi:10.1111/j.0006-341X.1999.00997.x)

44 Bilguvar K, Yasuno K, Niemela M, Ruigrok YM, von Und Zu Fraunberg M, van Duijn CM, van den Berg LH, Mane S, Mason CE, Choi M et al. Susceptibility loci for intracranial aneurysm in European and Japanese populations. Nature Genetics 200840 1472-1477. (doi:10.1038/ng.240)

45 Helgadottir A, Thorleifsson G, Magnusson KP, Gretarsdottir S, Steinthorsdottir V, Manolescu A, Jones GT, Rinkel GJ, Blankensteijn JD, Ronkainen A et al. The same sequence variant on 9p21 associates with myocardial infarction, abdominal aortic aneurysm and intracranial aneurysm. Nature Genetics 200840 217-224. (doi:10.1038/ng.72)

46 Chen Z, Qian Q, Ma G, Wang J, Zhang X, Feng Y, Shen C \& Yao Y. A common variant on chromosome 9p21 affects the risk of early-onset coronary artery disease. Molecular Biology Reports 200936 889-893. (doi:10.1007/s11033-008-9259-7)

47 McPherson R, Pertsemlidis A, Kavaslar N, Stewart A, Roberts R, Cox DR, Hinds DA, Pennacchio LA, Tybjaerg-Hansen A, Folsom AR et al. A common allele on chromosome 9 associated with coronary heart disease. Science 2007316 1488-1491. (doi:10.1126/science.1142447)

48 Chang YC, Chiu YF, Liu PH, Shih KC, Lin MW, Sheu WH, Quertermous T, Curb JD, Hsiung CA, Lee WJ et al. Replication of genome-wide association signals of type 2 diabetes in Han Chinese in a prospective cohort. Clinical Endocrinology 201276 365-372. (doi:10.1111/j.1365-2265.2011.04175.x)

49 Zeggini E, Weedon MN, Lindgren CM, Frayling TM, Elliott KS, Lango H, Timpson NJ, Perry JR, Rayner NW, Freathy RM et al. Replication of genome-wide association signals in UK samples reveals risk loci for type 2 diabetes. Science 2007316 1336-1341. (doi:10.1126/science.1142364)

50 Shete S, Hosking FJ, Robertson LB, Dobbins SE, Sanson M, Malmer B, Simon M, Marie Y, Boisselier B, Delattre JY et al. Genome-wide association study identifies five susceptibility loci for glioma. Nature Genetics 200941 899-904. (doi:10.1038/ng.407)

51 Uno S, Zembutsu H, Hirasawa A, Takahashi A, Kubo M, Akahane T, Aoki D, Kamatani N, Hirata K \& Nakamura Y. A genome-wide association study identifies genetic variants in the CDKN2BAS locus associated with endometriosis in Japanese. Nature Genetics 201042 707-710. (doi:10.1038/ng.612)

52 Pharoah PD, Dunning AM, Ponder BA \& Easton DF. Association studies for finding cancer-susceptibility genetic variants. Nature Reviews. Cancer 20044 850-860. (doi:10.1038/nrc1476)

Received 6 June 2014

Revised version received 5 September 2014

Accepted 2 October 2014 